\title{
Modular Assembly of Dimeric HIV Fusion Inhibitor Peptides with Enhanced Antiviral Potency
}

\author{
Junpeng Xiao ${ }^{a, \dagger}$ and Thomas J. Tolbert ${ }^{b, *}$ \\ anterdisciplinary Biochemistry Graduate Program, Indiana University, Bloomington, IN 47405 \\ ${ }^{b}$ Department of Pharmaceutical Chemistry, The University of Kansas, 2095 Constant Ave. \\ Lawrence, KS, 66047
}

\section{Abstract}

The HIV-1 envelope gp120/gp41 glycoprotein complex plays a critical role in virus-host cell membrane fusion and has been a focus for the development of HIV fusion inhibitors. In this paper, we present the synthesis of dimers of HIV fusion inhibitor peptides C37H6 and CP32M, which target the trimeric gp41 in the pre-hairpin intermediate state to inhibit membrane fusion. Reactive peptide modules were synthesized using native chemical ligation and then assembled into dimers with varying linker lengths using $\mathrm{Cu}(\mathrm{I})$-catalyzed azide-alkyne cycloaddition (CuAAC) "click" chemistry. Cell-cell fusion inhibition assays demonstrated that dimers with a $(\mathrm{PEG})_{7}$ linker showed enhanced antiviral potency over the corresponding monomers. Moreover, the bioorthogonal nature of the CuAAC "click" reaction provides a practical way to assemble heterodimers of HIV fusion inhibitors. Heterodimers consisting of the T20-sensitive strain inhibitor $\mathrm{C} 37 \mathrm{H} 6$ and the T20-resistant strain inhibitor CP32M were produced that may have broader spectrum activities against both T20-sensitive and T20-resistant strains.

\section{Keywords}

HIV; Peptide; Dimeric HIV fusion inhibitor; C37H6; CP32M; Native chemical ligation; CuAAC

\begin{abstract}
The human immunodeficiency virus type 1 (HIV-1) is an enveloped virus, and its envelope glycoprotein complex gp120/gp41 plays a critical role in HIV entry into host cells. The current model of virus entry (Figure 1A) involves binding of the trimeric gp120 to the host cell CD4 receptor and chemokine co-receptors CCR5 or CXCR4. Upon binding, gp120 undergoes conformational changes and dissociates from gp41, which results in insertion of the N-terminal fusion peptide of gp41 into the host cell membrane and formation of a prehairpin intermediate. Later, the $\mathrm{N}$-terminal heptad repeat 1 region (HR1) and the C-terminal heptad repeat 2 region (HR2) of gp41 fold back to form a six-helix bundle. In this fusion active hairpin structure, the virus membrane and the host membrane are brought close
\end{abstract}

\footnotetext{
(c) 2013 The Authors. Published by Elsevier Ltd. All rights reserved.

"Corresponding author. Tel.: +1-785-864-1898; fax: +1-785-864-5736; tolbert@ku.edu.

$\dagger$ †resent address. Department of Pathology, Stanford University School of Medicine, 300 Pasteur Dr. Stanford, CA, 94305 USA

Publisher's Disclaimer: This is a PDF file of an unedited manuscript that has been accepted for publication. As a service to our customers we are providing this early version of the manuscript. The manuscript will undergo copyediting, typesetting, and review of the resulting proof before it is published in its final citable form. Please note that during the production process errors may be discovered which could affect the content, and all legal disclaimers that apply to the journal pertain.

Supplementary data

Supplementary data (detailed experimental procedures, ${ }^{1} \mathrm{H}$ and ${ }^{13} \mathrm{C}$ NMR spectra of 3, ESI-MS of C37H6, CP32M and 4-9, cell-cell fusion inhibition assay profiles of 10-15) associated with this article can be found, in the online version, at http://...
} 
enough for fusion. ${ }^{1,2}$ HIV fusion inhibitor peptides derived from the HR2 region of gp41 (referred to as C-peptides) were discovered to prevent hairpin structure formation by binding to the HR1 region of gp41 in the pre-hairpin intermediate. This stabilizes the pre-hairpin structure and consequently inhibits membrane fusion and viral entry. 3,4 Among these peptides, T20 (also known as DP-178, Enfuvirtide, and Fuzeon) ) $^{5,6}$ and C347 are wellstudied inhibitors with $\mathrm{IC}_{50}$ values in the $\mathrm{nM}$ range (Figure $1 \mathrm{~B}$ ). $\mathrm{T} 20$ is also the only member of this class of peptide fusion inhibitors approved by FDA as an antiretroviral drug. Although T20 has been successfully used in the treatment of HIV infection, a variety of T20-resistant HIV mutation strains have been isolated from patients. ${ }^{8}$ Therefore, new potent HIV fusion inhibitor peptides against T20-resistant HIV strains have been developed. ${ }^{9-15}$

Both structural and biochemical studies have demonstrated that gp120 and gp41 are active as trimers. ${ }^{16,17}$ Because of this, both gp120 and gp41 have three binding sites for their targets and for potential inhibitors. The trimeric states of gp120 and gp41 have been the focus for development of more potent inhibitors and vaccine candidates utilizing simultaneous multivalent interactions. Wang and co-workers have synthesized dimeric and trimeric CD4-mimetic miniproteins that target the CD4-binding sites of trimeric gp120 and block gp120 binding to CD4. These multivalent miniproteins showed enhanced antiviral activity over the monovalent miniprotein. ${ }^{18,19}$ Trimeric $\mathrm{N}$ - and C-peptides of gp41, designed by Tam and co-workers for mimicking the pre-hairpin intermediate of gp41, were more potent than the corresponding monomers and may be useful as vaccine candidates for blocking HIV infection..$^{20,21}$ Recently, We and other groups also developed dimeric and trimeric C-peptide HIV fusion inhibitors with improved potency. ${ }^{22-26}$ These studies demonstrate that multivalent approaches to targeting gp120 and gp41 can be utilized to increase inhibitor potency.

The $\mathrm{Cu}(\mathrm{I})$-catalyzed azide-alkyne cycloaddition, termed CuAAC "click" chemistry, is a highly chemoselective reaction that has been widely used to form selective conjugates of small molecules, peptides, and proteins for drug discovery and investigations of biological function. ${ }^{27-33}$ Recently, we have developed a novel strategy to synthesize homodimers and heterodimers of expressed proteins and peptides via a combination of native chemical ligation (NCL) $)^{34}$ and CuAAC. ${ }^{35}$ In this strategy, the N-terminus of proteins and peptides are first functionalized with azide and alkyne groups by NCL. The azide and alkyne groups are then coupled together to form protein homodimers or heterodimers through CuAAC. To develop more potent fusion inhibitor peptides, we present the application of this strategy to assemble homodimers of HIV fusion inhibitor peptides C37H6, ${ }^{36,37}$ an analog of the HIV fusion inhibitor C34, and CP32M, ${ }^{9}$ a newly developed HIV fusion inhibitor against both T20-sensitive and T20-resistant strains targeting the trimeric gp41 in the pre-hairpin intermediate (peptide inhibitor sequences shown in Figure 1C). Moreover, the bioorthogonal nature of the $\mathrm{CuAAC}$ reaction also provides us a practical way to assemble heterodimers of $\mathrm{C} 37 \mathrm{H} 6$ and $\mathrm{CP} 32 \mathrm{M}$ that are functionalized with alkyne and azide moieties respectively. The heterodimers assembled in this way could have broader spectrum activities against both T20-sensitive and T20-resistant strains due to the presence of both the T20sensitive strain inhibitor C37H6 and the T20-resistant strain inhibitor CP32M. Treatment of HIV infection with heterodimers made up of monomeric HIV fusion inhibitors active against different drug resistant strains could also potentially slow or prevent the development of drug-resistance. Functionalization of peptides with alkyne and azide groups by NCL requires alkyne and azide thioesters and $\mathrm{N}$-terminal cysteine containing peptides (Scheme 1), which were generated by tobacco etch virus NIa (TEV) protease cleavage. ${ }^{38} \mathrm{~A}$ fusion protein, GPRT-C37H6, that contains a TEV protease cleavage sequence between the carrier protein GPRT and C37H6 was expressed and purified from E. coli as described previously. ${ }^{37}$ Treatment of this fusion protein with TEV protease released the C37H6 peptide with an N-terminal cysteine (Figure S1A). Due to the hydrophobic nature of the 
CP32M peptide, the carrier protein SUMO was used as the fusion partner because of its ability to enhance protein expression and solubility. ${ }^{39,40}$ Similarly, the fusion protein SUMO-CP32M that contains the TEV protease cleavage sequence was expressed, purified and treated with TEV protease to produce $\mathrm{N}$-terminal cysteine containing CP32M (Figure $\mathrm{S} 2 \mathrm{~A}$ ). The cleaved $\mathrm{C} 37 \mathrm{H} 6$ and $\mathrm{CP} 32 \mathrm{M}$ peptides were separated from their fusion partners by $\mathrm{Ni}^{2+}$-NTA affinity chromatography, and then further purified by reverse phase HPLC and lyophilized. The alkyne thioester $\mathbf{1}$ and the azide thioester $\mathbf{2}$ were synthesized as described previously. ${ }^{35}$ An azide thioester $\mathbf{3}$ with a polyethylene glycol $(\mathrm{PEG})_{7}$ linker was also synthesized to allow the production of dimers with an extended linker between peptide monomers (Scheme S1).

The alkyne functionalized C37H6 (alkyne-C37H6 4) and azide functionalized C37H6 (azide-C37H6 5 and azide-PEG-C37H6 6) were obtained by incubating $2 \mathrm{mg} / \mathrm{mL}$ of C37H6 with $4 \mathrm{mM}$ alkyne thioester $\mathbf{1}$, and azide thioesters $\mathbf{2}$ and $\mathbf{3}$ respectively, in the presence of $30 \mathrm{mM}$ sodium 2-mercaptoethanesulfonate in denaturing buffer (7 M guanidine hydrochloride, $100 \mathrm{mM}$ sodium phosphate $\mathrm{pH} 7.5$ ) (Scheme 1B). After $24 \mathrm{~h}$ the reaction mixtures were purified by reverse phase HPLC and lyophilized to give $\mathbf{4 , 5}$ and $\mathbf{6}$ (Figure $\mathrm{S} 1 \mathrm{~B}, \mathrm{C}$ and $\mathrm{D}$ ). The same reaction conditions were also used to produce alkyne-CP32M 7, azide-CP32M 8 and azide-PEG-CP32M 9 (Scheme 1C, Figure S2B, C and D).

To assemble homodimers of HIV fusion inhibitors, alkyne functionalized peptide monomers and azide functionalized peptide monomers were coupled together through $\mathrm{CuAAC}$. Incubation of alkyne-C37H6 4 with azide-C37H6 5 or azide-PEG-C37H6 6 in the presence of $1 \mathrm{mM} \mathrm{CuSO}_{4}$ and $2 \mathrm{mM} \mathrm{L}$-ascorbic acid in denaturing buffer gave the C37H6-C37H6 homodimer $\mathbf{1 0}$ or C37H6-PEG-C37H6 homodimer 11 with a short and long linker between two monomers, respectively (Figure $2 \mathrm{~A}$ and $\mathrm{B}$ ). The dimer products were separated from the unreacted monomers by size-exclusion chromatography and further purified by reverse phase HPLC and lyophilized (74\% yield for $\mathbf{1 0}$ and $63 \%$ yield for 11). The analytical HPLC and ESI-MS profiles of purified homodimers $\mathbf{1 0}$ and $\mathbf{1 1}$ are shown in Figure $2 \mathrm{C}$ and D, which indicates the desired products were obtained with high purity. CP32M-CP32M homodimer 12 with a short linker and CP32M-PEG-CP32M homodimer 13 with a long $(\mathrm{PEG})_{7}$ linker were also produced, purified and characterized using the same procedures (57\% yield for $\mathbf{1 2}$ and 55\% yield for $\mathbf{1 3}$ ) (Figure 3).

To examine whether the divalent HIV fusion inhibitors have increased antiviral activities compared to monovalent inhibitors, the antiviral activities were examined using a luciferasebased cell-cell fusion inhibition assay. ${ }^{41}$ Briefly, two cell lines, HL2/3 ${ }^{42}$ and TZM-bl ${ }^{43}$, were used in this assay. The HL2/3 cell line stably expresses HIV Gag, Env, Tat, Rev and Nef proteins. The TZM-bl indicator cell line stably expresses large amounts of CD4 and CCR5 and contains integrated copies of the luciferase gene under control of the HIV-1 promoter. Fusion between HL2/3 cells and TZM-bl cells can be monitored by luciferase activity induced by cell fusion, and can also be inhibited by the addition of HIV fusion inhibitor peptides into the cell culture media. Results from three independent assays are summarized in Table 1 (also see Figure S3).

As we expected, the bacterial expressed fusion inhibitors $\mathrm{C} 37 \mathrm{H} 6$ and $\mathrm{CP} 32 \mathrm{M}$ are active to block cell-cell fusion with an $\mathrm{IC}_{50}$ of $4.4 \mathrm{nM}$ and $3.3 \mathrm{nM}$, respectively. Although the homodimers with a short linker, C37H6-C37H6 10 and CP32M-CP32M 12, showed very little or even no improvement of potency over the corresponding monomers (1.6-fold and 0.8 -fold, respectively), the homodimers with a long (PEG) 7 linker, C37H6-PEG-C37H6 11 and CP32M-PEG-CP32M 13, showed approximately 4-fold enhanced antiviral potency over the corresponding monomers. The difference in activities among the dimers with different linker length indicates that the space between the two monomer units may have some 
influence on the activities of the dimers. The spacing in $\mathbf{1 0}$ and $\mathbf{1 2}$ might be too short to allow the second peptide monomer of the dimer to reach the second binding site of trimeric gp41 in the pre-hairpin state while the first monomer is simultaneously binding to the first binding site of gp41. Therefore, these two dimers may only act as monomeric inhibitors. In contrast, $\mathbf{1 1}$ and $\mathbf{1 3}$ have a longer $(\mathrm{PEG})_{7}$ linker, which apparently gives the two monomer units enough space to bind two different binding sites on trimeric gp41 simultaneously to achieve higher affinity binding and consequently obtain enhanced antiviral potency.

In addition to homodimers, the bio-orthogonal nature of the $\mathrm{CuAAC}$ reaction also provides us a more practical way to assemble heterodimers of HIV fusion inhibitors with broader spectrum activities by joining a T20-sensitive strain inhibitor with a T20-resistant strain inhibitor that are functionalized with alkyne and azide moieties respectively. As an example, two heterodimers C37H6-CP32M 14 and C37H6-PEG-CP32M 15 were synthesized by coupling azide-C37H6 5 and azide-PEG-C37H6 6 with alkyne-CP32M 7, respectively (Figure 4A and B). After purification and lyophilization (68\% yield for $\mathbf{1 4}$ and $56 \%$ yield for 15), the products were characterized by analytical HPLC and ESI-MS (Figure 4C and D), which indicated the desired heterodimers were produced. The antiviral activities of $\mathbf{1 4}$ and 15 were determined by cell-cell fusion inhibition assays as shown in Table 1 . Similar to the homodimers 10 and 12, the heterodimer C37H6-CP32M 14 showed no improvement of antiviral activity, presumably due to the short linker between the monomers. However, the heterodimer C37H6-PEG-CP32M 15 inhibited the cell-cell fusion with an $\mathrm{IC}_{50}$ of $1.2 \mathrm{nM}$, which was 3.7-fold more potent than the C37H6 monomer and 2.8-fold more potent than the $\mathrm{CP} 32 \mathrm{M}$ monomer. In addition to improved potency, the heterodimers of C37H6 and CP32M should have broader activity against both T20-sensitive and T20-resistant virus strains. Moreover, treatment of HIV infection with heterodimers of HIV fusion inhibitors could potentially slow or prevent the development of drug-resistance. This is because the two peptides in the heterodimer have different sequences and different binding sites on gp41, and it will likely require more mutations to create resistance to the heterodimer than to either monomeric inhibitor alone.

In conclusion, a series of homodimers and heterodimers of HIV fusion inhibitor peptides C37H6 and CP32M have been assembled using a combination of NCL with CuAAC. Peptide inhibitors were produced by recombinant protein expression and then ligated to alkyne and azide linkers using NCL. Alkyne and azide adapted HIV fusion inhibitor modules could then be assembled to produce homodimeric and heterodimeric inhibitors with varied linker lengths by utilizing CuAAC. Cell-cell fusion inhibition assays demonstrated that although the dimers with a short linker did not improve antiviral activities compared to monomers, the dimers with a longer $(\mathrm{PEG})_{7}$ linker did show about 4 -fold enhanced antiviral potency over the corresponding monomers. Furthermore, by synthesizing a heterodimer consisting of T20-sensitive strain inhibitor C37H6 and T20-resistant strain inhibitor CP32M, it is likely that the resulting heterodimeric inhibitor will have a broader spectrum activity against both T20-sensitive and T20-resistant virus strains. Treatment of HIV infection with heterodimers of HIV fusion inhibitors could also potentially slow or prevent the development of drug-resistance. This strategy could be applied to assemble homodimers and heterodimers, or even higher order multimers of different types of HIV inhibitors to create a library of HIV inhibitors with potentially greater potency, broader specificity and less chance for the development of drug-resistance.

\section{Supplementary Material}

Refer to Web version on PubMed Central for supplementary material. 


\section{Acknowledgments}

We gratefully acknowledge Dr. Vasily Gelfanov and Dr. Richard DiMarchi for cell culture discussions and facilities. We thank Rui Chen for the assistant in analytical HPLC. The following reagents were obtained from the AIDS Research and Reference Reagent Program, Division of AIDS, NIAID, NIH: HL2/3 from Dr. Barbara K. Felber and Dr. George N. Pavlakis; TZM-bl from Dr. John C. Kappes, Dr. Xiaoyun Wu, and Tranzyme Inc.

\section{References}

1. Chan DC, Kim PS. Cell. 1998; 93:681. [PubMed: 9630213]

2. Gallo SA, Finnegan CM, Viard M, Raviv Y, Dimitrov A, Rawat SS, Puri A, Durell S, Blumenthal R. Biochim. Biophys. Acta. 2003; 1614:36. [PubMed: 12873764]

3. Krambovitis E, Porichis F, Spandidos DA. Acta. Pharmacol. Sin. 2005; 26:1165. [PubMed: 16174430]

4. Briz V, Poveda E, Soriano V. J. Antimicrob. Chemother. 2006; 57:619. [PubMed: 16464888]

5. Wild CT, Shugars DC, Greenwell TK, McDanal CB, Matthews TJ. Proc. Natl. Acad. Sci. U.S.A. 1994; 91:9770. [PubMed: 7937889]

6. Matthews T, Salgo M, Greenberg M, Chung J, DeMasi R, Bolognesi D. Nat. Rev. Drug Discov. 2004; 3:215. [PubMed: 15031735]

7. Malashkevich VN, Chan DC, Chutkowski CT, Kim PS. Proc. Natl. Acad. Sci. U.S.A. 1998; 95:9134. [PubMed: 9689046]

8. Greenberg ML, Cammack N. J. Antimicrob. Chemother. 2004; 54:333. [PubMed: 15231762]

9. He Y, Cheng J, Lu H, Li J, Hu J, Qi Z, Liu Z, Jiang S, Dai Q. Proc. Natl. Acad. Sci. U.S.A. 2008; 105:16332. [PubMed: 18852475]

10. Izumi K, Kodama E, Shimura K, Sakagami Y, Watanabe K, Ito S, Watabe T, Terakawa Y, Nishikawa H, Sarafianos SG, Kitaura K, Oishi S, Fujii N, Matsuoka M. J. Biol. Chem. 2009; 284:4914. [PubMed: 19073606]

11. Naito T, Izumi K, Kodama E, Sakagami Y, Kajiwara K, Nishikawa H, Watanabe K, Sarafianos SG, Oishi S, Fujii N, Matsuoka M. Antimicrob. Agents Chemother. 2009; 53:1013. [PubMed: 19114674]

12. He Y, Xiao Y, Song H, Liang Q, Ju D, Chen X, Lu H, Jing W, Jiang S, Zhang L. J. Biol. Chem. 2008; 283:11126. [PubMed: 18303020]

13. De Feo CJ, Weiss CD. Viruses. 2012; 4:3859. [PubMed: 23342377]

14. Shi W, Cai L, Lu L, Wang C, Wang K, Xu L, Zhang S, Han H, Jiang X, Zheng B, Jiang S, Liu K. Chem. Commun. 2012; 48:11579.

15. Chong H, Yao X, Qiu Z, Sun J, Zhang M, Waltersperger S, Wang M, Liu SL, Cui S, He Y. FASEB J. 2013; 27:1203. [PubMed: 23233535]

16. Zhu P, Chertova E, Bess J Jr, Lifson JD, Arthur LO, Liu J, Taylor KA, Roux KH. Proc. Natl. Acad. Sci. U.S.A. 2003; 100:15812. [PubMed: 14668432]

17. Salzwedel K, Berger EA. Proc. Natl. Acad. Sci. U.S.A. 2000; 97:12794. [PubMed: 11050186]

18. Li H, Song H, Heredia A, Le N, Redfield R, Lewis GK, Wang LX. Bioconjugate Chem. 2004; 15:783.

19. Li H, Guan Y, Szczepanska A, Moreno-Vargas AJ, Carmona AT, Robina I, Lewis GK, Wang LX. Bioorg. Med. Chem. 2007; 15:4220. [PubMed: 17412600]

20. Tam JP, Yu Q. Org. Lett. 2002; 4:4167. [PubMed: 12423113]

21. Sadler K, Zhang Y, Xu J, Yu Q, Tam JP. Biopolymers. 2008; 90:320. [PubMed: 18338371]

22. Nomura W, Hashimoto C, Suzuki T, Ohashi N, Fujino M, Murakami T, Yamamoto N, Tamamura H. Bioorg. Med. Chem. 2013; 21:4452. [PubMed: 23800723]

23. Ling Y, Xue H, Jiang X, Cai L, Liu K. Bioorg. Med. Chem. Lett. 2013; 23:4770. [PubMed: 23906421]

24. Nomura W, Hashimoto C, Ohya A, Miyauchi K, Urano E, Tanaka T, Narumi T, Nakahara T, Komano JA, Yamamoto N, Tamamura H. ChemMedChem. 2012; 7:205. [PubMed: 22247043]

25. Francis JN, Redman JS, Eckert DM, Kay MS. Bioconjugate Chem. 2012; 23:1252. 
26. Xiao J, Hamilton BS, Tolbert TJ. Bioconjugate Chem. 2010; 21:1943.

27. Rostovtsev VV, Green LG, Fokin VV, Sharpless KB. Angew. Chem. Int. Ed. 2002; 41:2596.

28. Eger S, Scheffner M, Marx A, Rubini M. J. Am. Chem. Soc. 2010; 132:16337. [PubMed: 21033666]

29. Richter S, Ramenda T, Bergmann R, Kniess T, Steinbach J, Pietzsch J, Wuest F. Bioorg. Med. Chem. Lett. 2010; 20:3306. [PubMed: 20452768]

30. Yang Y, Kluger R. Chem. Commun. 2010; 46:7557.

31. Li X. Chem. Asian J. 2011; 6:2606. [PubMed: 22043498]

32. Hou J, Liu X, Shen J, Zhao G, Wang PG. Expert Opin. Drug Discov. 2012; 7:489. [PubMed: 22607210]

33. Weikart ND, Sommer S, Mootz HD. Chem. Commun. 2012; 48:296.

34. Dawson PE, Muir TW, Clark-Lewis I, Kent SB. Science. 1994; 266:776. [PubMed: 7973629]

35. Xiao J, Tolbert TJ. Org. Lett. 2009; 11:4144. [PubMed: 19705863]

36. Root MJ, Kay MS, Kim PS. Science. 2001; 291:884. [PubMed: 11229405]

37. Tolbert TJ, Franke D, Wong CH. Bioorg. Med. Chem. 2005; 13:909. [PubMed: 15653356]

38. Tolbert TJ, Wong CH. Angew. Chem. Int. Ed. 2002; 41:2171.

39. Marblestone JG, Edavettal SC, Lim Y, Lim P, Zuo X, Butt TR. Protein Sci. 2006; 15:182. [PubMed: 16322573]

40. Xiao J, Burn A, Tolbert TJ. Bioconjugate Chem. 2008; 19:1113.

41. Wexler-Cohen Y, Shai Y. FASEB J. 2007; 21:3677. [PubMed: 17575260]

42. Ciminale V, Felber BK, Campbell M, Pavlakis GN. AIDS Res. Hum. Retroviruses. 1990; 6:1281. [PubMed: 2078409]

43. Wei X, Decker JM, Liu H, Zhang Z, Arani RB, Kilby JM, Saag MS, Wu X, Shaw GM, Kappes JC. Antimicrob. Agents Chemother. 2002; 46:1896. [PubMed: 12019106] 

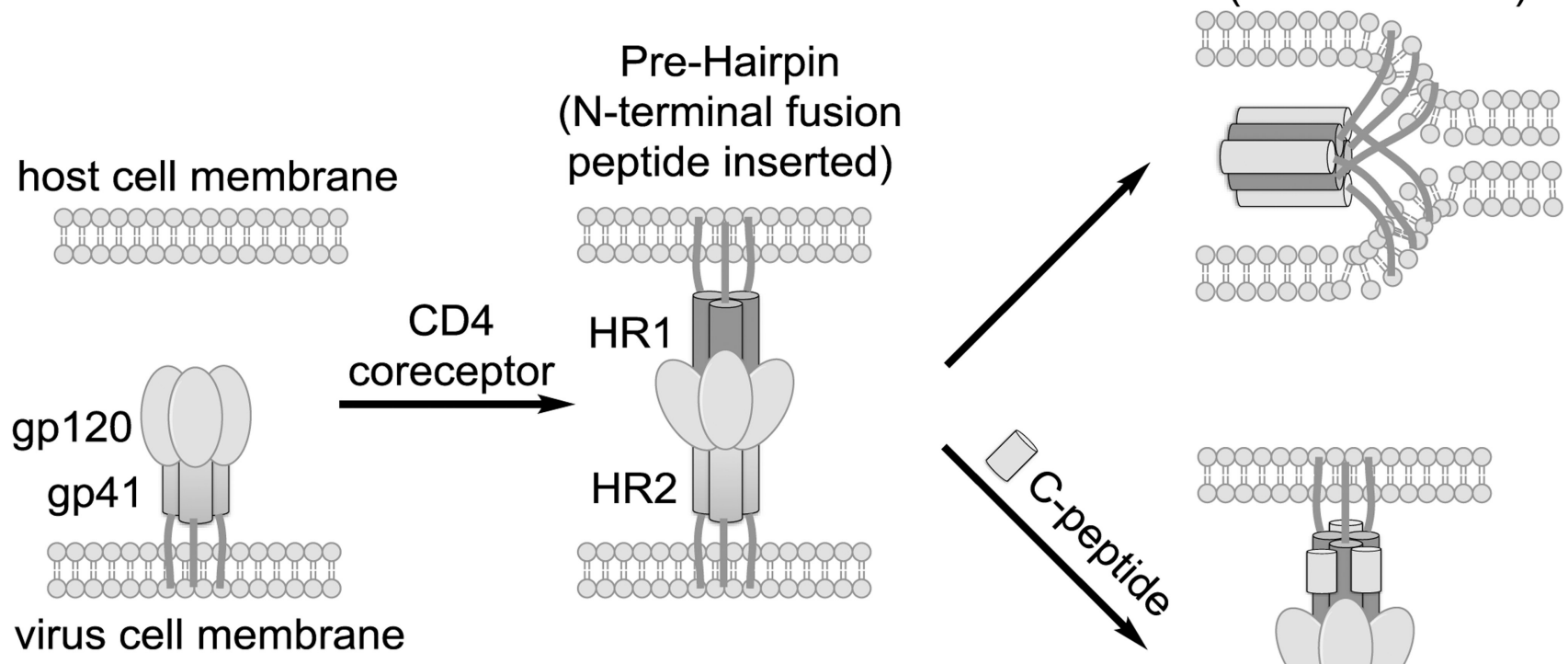

virus cell membrane

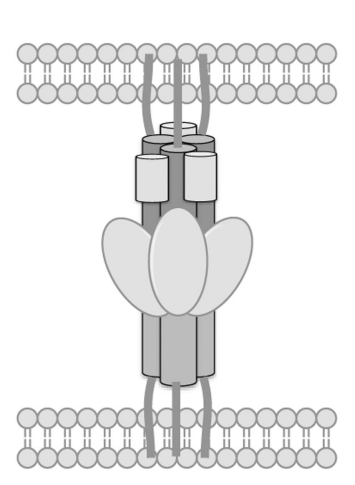

(B)

C34: WMEWDREINNYTSLIHSLIEESQNQQEKNEQELL
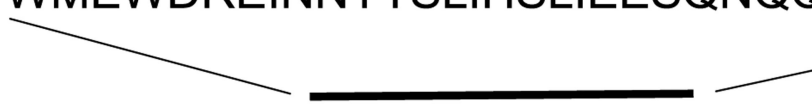

\begin{tabular}{|l|l|l|l|l|l|l|l|}
\hline FP & Heptad repeat 1(HR1) & & Heptad repeat 2(HR2) & TR & TM & CP \\
\hline
\end{tabular}

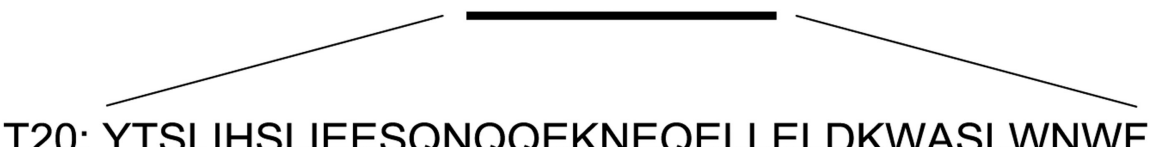

(C)

\section{C37H6: HTTWMEWDREINNYTSLIHSLIEESQNQQEKNEQELLGHHHHHH CP32M: VEWNEMTWMEWEREIENYTKLIYKILEESQEQ}

Figure 1.

HIV fusion and HIV fusion inhibitors. (A) Schematic representation of the mechanism for HIV membrane fusion and fusion inhibition by C-peptides. ${ }^{1,2}$ (B) Schematic representation of structure of gp41, and the locations and sequences of HIV fusion inhibitor C34 and T20. FP, fusion peptide; TR, tryptophan-rich domain; TM, transmembrane domain; $\mathrm{CP}$, cytoplasmic domain. (C) The sequences of C37H6 and CP32M. 
(A)

(B)

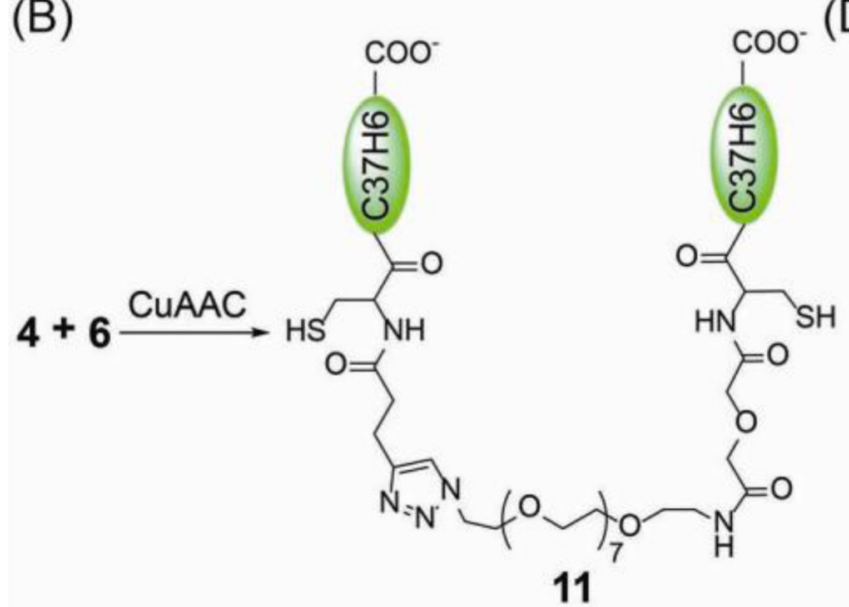

(C)

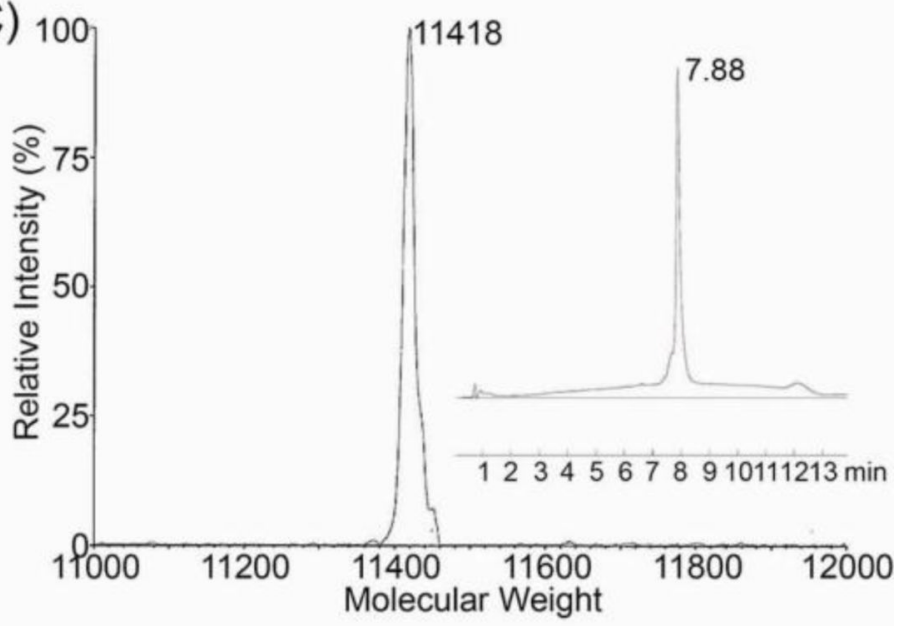

Figure 2.

Synthesis of C37H6 homodimers. (A) Synthesis of C37H6-C37H6 homodimer 10. (B) Synthesis of C37H6-PEG-C37H6 homodimer 11. (C) Analytical HPLC profile and ESI-MS of 10, calcd 11419, found 11418. (D) Analytical HPLC profile and ESI-MS of 11, calcd 11873 , found 11872 . 
(A)

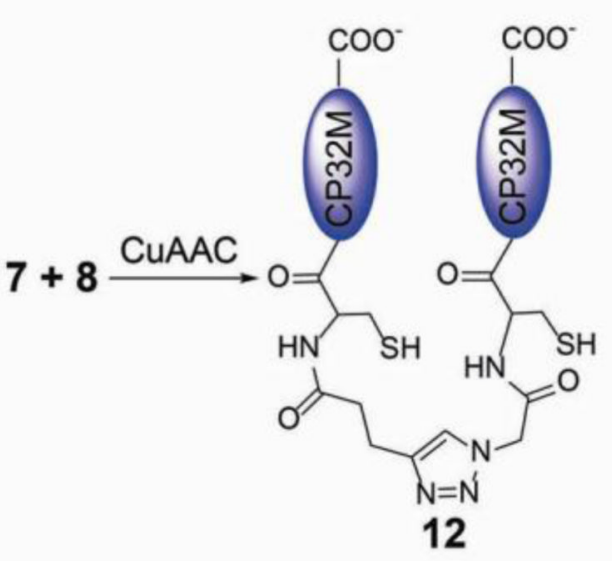

(B)

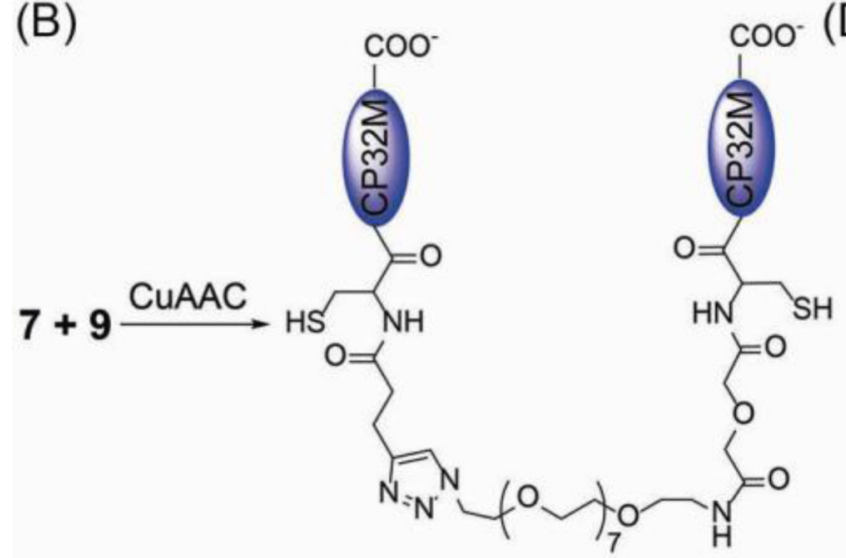

13
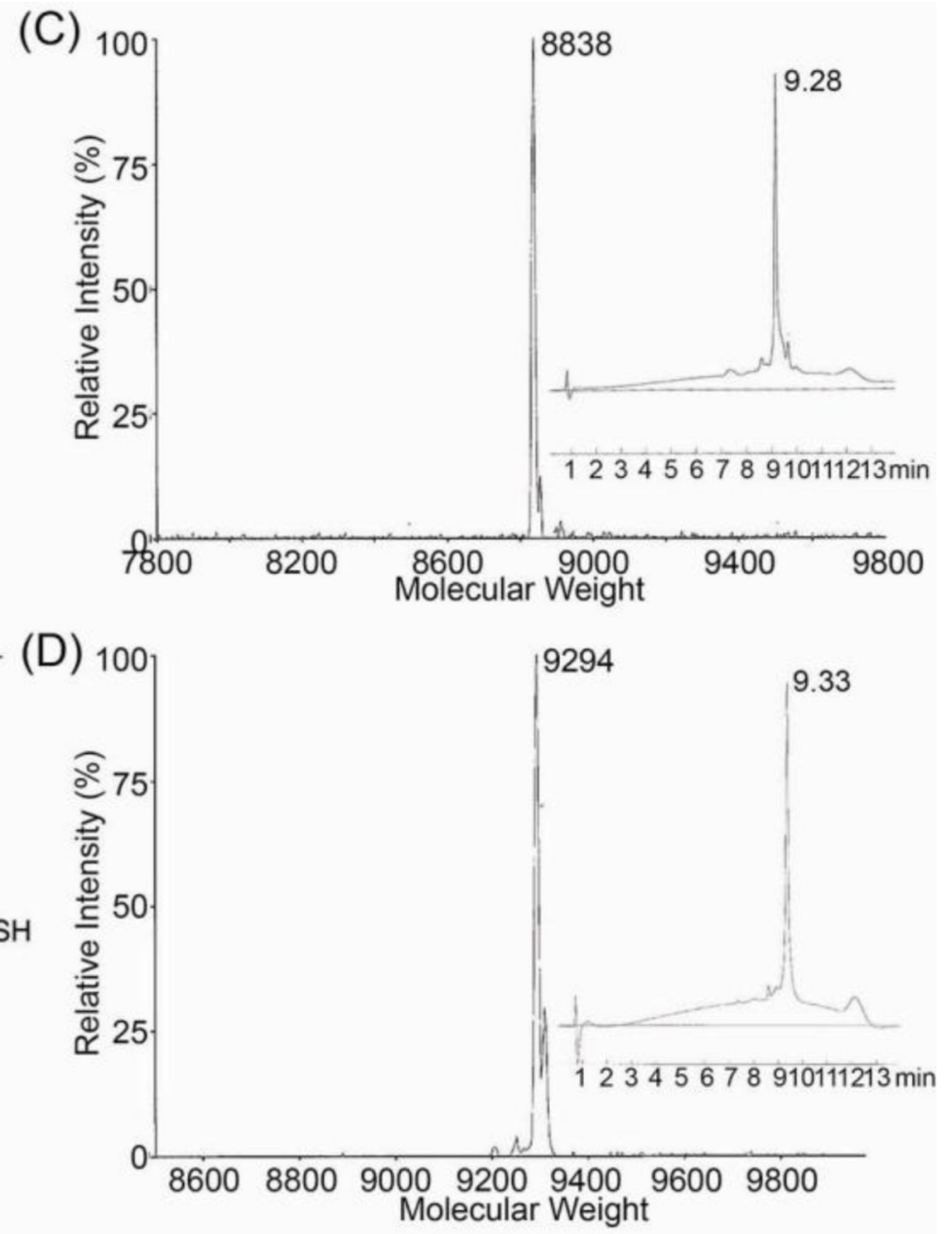

Figure 3.

Synthesis of CP32M homodimers. (A) Synthesis of CP32M-CP32M homodimer 12. (B) Synthesis of CP32M-PEG-CP32M homodimer 13. (C) Analytical HPLC profile and ESIMS of 12, calcd 8839, found 8838. (D) Analytical HPLC profile and ESI-MS of 13, calcd 9294, found 9294. 
(A)

(B)

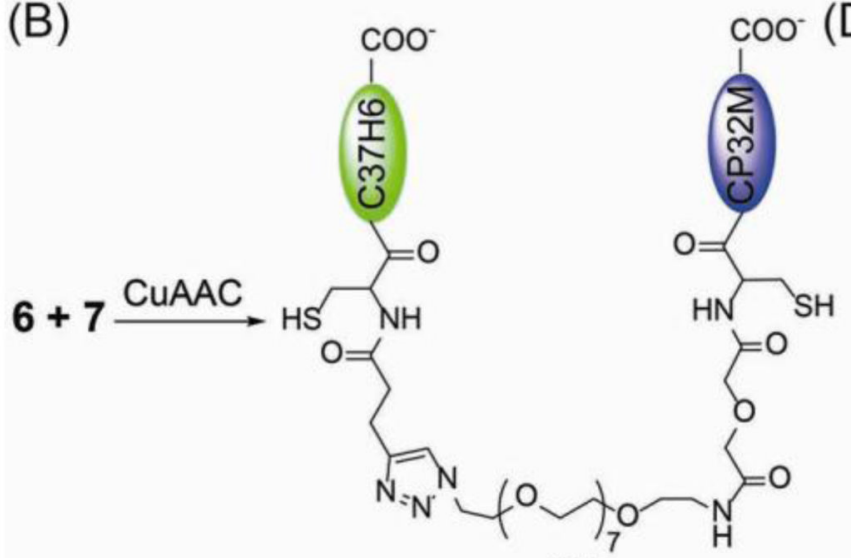

15
(C)

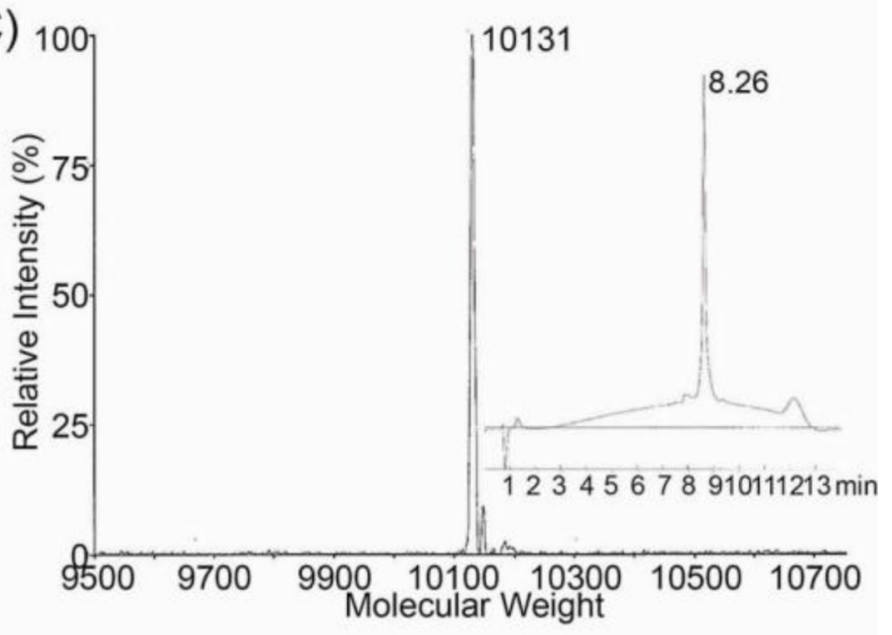

Figure 4.

Synthesis of C37H6-CP32M heterodimers. (A) Synthesis of C37H6-CP32M heterodimer 14.

(B) Synthesis of C37H6-PEG-CP32M heterodimer 15. (C) Analytical HPLC profile and ESI-MS of 14, calcd 10130, found 10131. (D) Analytical HPLC profile and ESI-MS of 15, calcd 10584, found 10584 . 
(A)<smiles>C#CCCC(=O)SCC(=O)O</smiles><smiles>N#CCSC(=O)CC(=O)O</smiles><smiles>COC(=O)CCSC(=O)COCC(=O)NCCOCCOC(C)C</smiles>

(B)<smiles>C#CCCC(=O)NC(CS)C(=O)C1CCCCC1CC(=O)[O-]</smiles><smiles>CCCCCC(=O)C(=O)CCCCCCCC(=O)C(N)CS</smiles>

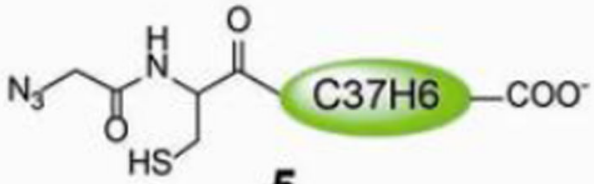

(C)

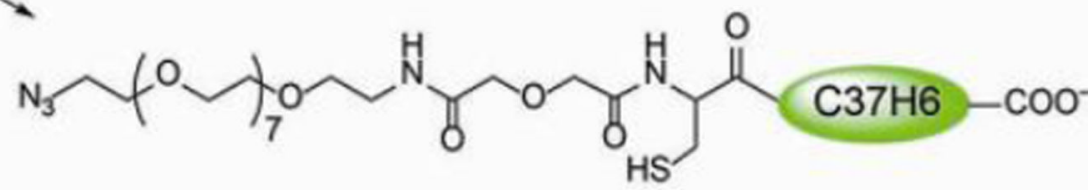<smiles>C#CCCC(=O)NC(CS)C(=O)C1(C(=O)O)CCCCC1C(=O)[O-]</smiles>

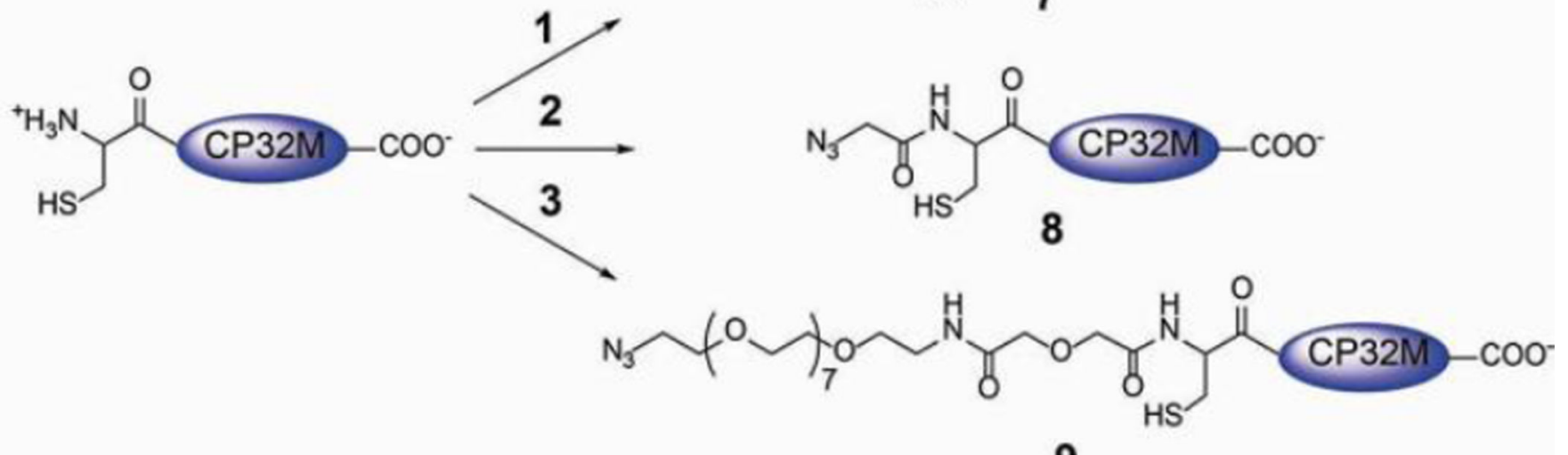

9

Scheme 1.

Functionalization of C37H6 and CP32M with Alkyne and Azide Groups by NCL. (A) Chemical Structure of alkyne and azide thioesters 1-3. (B) Synthesis of alkyne and azide functionalized C37H6 4-6. (C) Synthesis of alkyne and azide functionalized CP32M 7-9. 
Table 1

Antiviral activities of the HIV fusion inhibitors

\begin{tabular}{llll}
\hline Compound & IC $_{\mathbf{5 0}}(\mathbf{n M})$ & $\begin{array}{l}\text { Relative } \\
\text { activity } \\
\text { (C37H6) }\end{array}$ & $\begin{array}{l}\text { Relative } \\
\text { Activity } \\
\text { (CP32M) }\end{array}$ \\
\hline C37H6 & $4.4 \pm 0.1$ & 1.0 & - \\
CP32M & $3.3 \pm 0.3$ & - & 1.0 \\
C37H6-C37H6 10 & $2.7 \pm 0.3$ & 1.6 & - \\
C37H6-PEG-C37H6 11 & $1.1 \pm 0.1$ & 4.0 & - \\
CP32M-CP32M 12 & $4.2 \pm 0.2$ & - & 0.8 \\
CP32M-PEG-CP32M 13 & $0.8 \pm 0.1$ & - & 4.1 \\
C37H6-CP32M 14 & $4.9 \pm 0.4$ & 0.9 & 0.7 \\
C37H6-PEG-CP32M 15 & $1.2 \pm 0.1$ & 3.7 & 2.8 \\
\hline
\end{tabular}

